AperTO - Archivio Istituzionale Open Access dell'Università di Torino

\title{
Young adult occupational transition regimes in Europe: does gender matter?
}

\section{This is a pre print version of the following article:}

Original Citation:

\section{Availability:}

This version is available http://hdl.handle.net/2318/1762453

since 2020-11-11T16:38:06Z

Published version:

DOI:10.1108/IJSSP-04-2017-0052

Terms of use:

Open Access

Anyone can freely access the full text of works made available as "Open Access". Works made available under a Creative Commons license can be used according to the terms and conditions of said license. Use of all other works requires consent of the right holder (author or publisher) if not exempted from copyright protection by the applicable law. 
THIS IS A PRE-PRINT VERSION OF THE ARTICLE.

THE FINAL VERSION IS AVAILABLE HERE:

https://www.emerald.com/insight/content/doi/10.1108/IJSSP-04-2017-0052/full/html

"Young adult occupational transition regimes in Europe: does gender matter?"

\begin{tabular}{|r|l|}
\hline Journal: & International Journal of Sociology and Social Policy \\
\hline Manuscript ID & IJSSP-04-2017-0052.R1 \\
\hline Manuscript Type: & Original Article \\
\hline Keywords: & Youth, Labour market, Gender \\
\hline \multicolumn{2}{|l}{} \\
\hline
\end{tabular}




\section{Young adult occupational transition regimes in Europe:}

\section{does gender matter?}

\section{Introduction}

There have been many studies on patterns of entry for young people into the labour market and on the early stages of their employment careers (Breen, 2005; Gangl, 2003; Brzinski-Fay, 2007; Blossfeld et al., 2008). What often emerges from these studies is that growing work career insecurity has a particular impact on youth, who appear to have been more affected than other cohorts of workers by the labour market deregulation and social safety net reductions that began in 1980s and 1990s (EspingAndersen and Regini 2000; Blossfeld et al. 2005; Standing 2011).

The objective of this paper is to achieve a greater understanding of the transitions young adults experience into and out of the labour market and the influence that gender and married/cohabiting status have on employment careers. The paper contributes to aspects of the de-standardization of the life course addressed by previous literature.

First, we focus on a specific category, young adults from 25 to 34 years old, which is increasingly recognized as a critical stage in the life course though it receives less attention than its younger counterpart (15-24). Indeed, a growing body of scientific literature shows that over the past 10 years the problematic search for greater stability over time is not limited to the very early stages of the employment career, but extends to so-called young adults (Furlong 2009; Heinz 2009). Moreover, the general process of 
expansion in education in recent decades (Schofer and Meyer 2005) has had the effect of postponing entry into the labour market and subsequent stabilization (Mortimer et al., 2005).

Second, focusing on the de-standardization of life paths from a gender perspective, this paper contributes new evidence on the high variability of labour market outcomes across countries and identifies the persistent crucial role played by institutional settings. In investigating this issue, we integrate the family structure dimension into welfare models, employment regimes and educational systems, in order to highlight the different effects of the institutional context on the transitions of young adult men and women. Furthermore, the different effects played by married/cohabiting status on the occupational careers of young adult men and women analyzed in this paper, acknowledges the importance of family dynamics on work careers (Vosko 2000).

Lastly, the paper advances the idea of considering multiple transition paths into and out of the labour market as a means of highlight the circularity of these processes. This analysis will allow us to identify a variety of young adult occupational transition regimes in Europe, focusing on gender differences.

Our analysis focuses on the 25-34 age group in four European countries - Italy, Netherlands, United Kingdom and Norway - that are representative of different youth transition regimes (Walther 2006). The starting point is the assumption that variations in transitions depend on the specific institutional context of a country. The time frame 
considered - from 2006 to 2012 - is composed of an initial period up to 2008, representative of the pre-crisis situation, and a second period marking the beginning of the actual crisis phase. A comparison between the two different periods enables us to assess to what extent changes in economic conditions influence the employment transition regimes of young adults and, at the same time, assess any influences due to a country's institutional frameworks.

\section{Young adult transitions: the impact of individual and institutional conditions}

Significant societal transformations, including globalization and the growing international competition; the rise of technological change, which has facilitated the offshore outsourcing of work; the weakening of labour unions; have led to the reduction of the employment security of large parts of the working population (Piore and Sabel, 1987; Esping-Andersen and Regini, 2000; Blossfeld et.al., 2008; Kalleberg 2009). These changes have been especially severe for young people who are facing considerable hurdles in launching their work careers (Piotrowski et.al. 2015). In such a context, individual biographies are undergoing a process of de-standardization. Though the predominant social risks in the industrial age were associated with the loss of a secure job (employed or self-employed) and with the period of inactivity (pension), the majority of social risks in the post-industrial age arise in the first phase of the life course (Taylor-Gooby, 2004; Ranci, 2010; Clasen and Clegg, 2011). These risks may persist 
over time, due to an increasing difficulty in stabilizing personal employment status and income, and are therefore not limited to the very early stages of the employment career but extend into the subsequent period involving young adults.

It is necessary to observe how the different cohorts of the labour market are affected differently by transitions and the quality of their paths. Transitions refer to "changes in state that are more or less abrupt" (Elder 1985: 31) and that tend to condense around particular critical moments (Schmid 2002): the transition from school into work or from living at home to independent living, job transitions, and the transition from work into retirement. In this regard, comparative international studies focused on job transitions of young adults show that the younger generations in Europe are increasingly forced into temporary work, experience high risks of unemployment and have to wait many years before they are able to stabilize their employment status (Blossfeld et al., 2008). Although precarious ${ }^{1}$ work conditions can be found in every type of European society, there are considerable differences in the quality of the transitions that young adults experience across countries. These differences can be attributed to the historically established national institutions that filter the changes and shape the institutional linkage between the transition structure, acting as a sort of "intervening variable". This framework gives rise to distinct occupational regimes of youth transitions with 3 institutional areas in particular acting as mediators: welfare regimes (Esping Andersen, 1999; Arts and Gelissen, 2010); employment regimes (Gallie and Paugam, 2000; Gallie, 
2007); and education and training systems (Blossfeld et al., 2008). These institutional processes tend to have a selective impact on youth, producing different effects depending on gender.

With regard to gender inequalities, women across Europe tend to show lower participation and employment rates, higher unemployment rates and a negative gender pay gap (Eurostat 2016). Besides, most recent cohorts enter flexible labour markets with insecure jobs which negatively affect women more than men, who experience greater risk of getting entrapped in low quality jobs and precarious careers (Blossfeld and Hofmeister 2008; Blossfeld et al. 2011). Much of this gap is determined by the fact that working women are affected by a 'double burden' due to their role of caregiver and responsible for the household, and their duties on paid job (Saraceno and Keck 2010; Blossfeld and Drobnič 2001). The analysis of this phenomenon among young adults offers insight into the ways in which gender differences originate in a stage in life in which caring activities grow and reconciling work and life becomes a crucial aspect of employment careers.

Finally, the analysis of young adult occupational transition regimes shows that inequalities do not only refer to a gender divide, since inequalities among women themselves are evident, these depending on the specific institutional context and on the intertwining effect of welfare regimes, employment regimes and educational systems. 
The four countries analyzed in the paper were selected for their particular combination of educational, employment and welfare systems, which makes each of them a good representative of four different regimes of youth transition. Indeed, building on the typology developed by Walther (2006), the four countries selected maximize the variation in terms of youth transition regimes. At one extreme of a hypothetical continuum, we placed Italy and the United Kingdom as representative of low-protective regimes for youth. The former is characterized by a labour market dualism that penalizes youth and women who bear the costs of a "flexibility at the edge". The latter is characterized by a liberal regime that combines low protection with supply-side activation through workfare policies. On the other extreme of the continuum, we placed Norway, as representative of a highly protective, universalistic regime, and the Netherlands, usually assigned to an employment-centered regime.

\section{Occupational regimes of youth transition. Institutional conditions in Italy, Netherlands, United Kingdom and Norway \\ Regimes of youth transition}

Italy has a sub-protective youth transition regime. This regime is characterized by a strong dualism in the labour market that is typical of Mediterranean countries (Barbieri and Scherer, 2005). The cost of flexibility is offloaded onto fixed-term contracts that are insecure and provide little protection. A critical element for the young is the increased 
probability, especially for the most recent cohorts entering the labour market, of getting no more than a temporary job in the first phase of their occupational careers, with high risks of a prolonged entrapment in a precarious career: this being especially the case for women (Berton et al., 2009; De Luigi and Rizza, 2011).

As regards welfare arrangements, a significant role has been assigned to the family and women in the care of children and the elderly; a situation that ends up penalizing poorly educated young women with young children who frequently exit the labour market. In this regard, many studies note (see e.g. Naldini and Saraceno, 2011 for a review) that in Italy work and life balance policies are very weak, reflecting persistent gender norms that regard unpaid work as a women's prerogative. For this reason, especially young women with low levels of education and poor jobs who tend to engage in more housework than their male partners, are significantly more likely to leave the labour market or full-time for part-time work.

The evolution of the Italian model of education and training results in dual effects on the transition from school to work. Primarily, it increases the level of education of young people in a framework of extremely weak demand for skilled labour, and the market is not able to absorb the increasing numbers of young people, especially female, exiting the school system with high levels of education (Reyneri and Pintaldi, 2013). Secondly, the relationship between vocational training and businesses is historically very weak in Italy and young people exiting education lack the professional knowledge 
that could facilitate their entry into the labour market. This disconnection between education and job-training therefore makes the transition from school to work problematic, which is reflected in very high levels of youth unemployment and prolonged precarious employment careers.

The Netherlands has an employment-centered youth transition regime (Walther, 2006). Traditionally, the Netherlands is characterized by a structure of centralized industrial relations negotiation, with an employment system that tends to be closed and oriented to the defense of the male breadwinner. The labour market was highly standardized with a protected core and a more precarious periphery. There was dynamic change in some areas following interventions in the 1990s, (Visser and Hemerijck, 1998). A return of wage moderation represented an adjustment to the changing conditions of world markets, and extraordinary growth in part-time work led to a massive increase in female employment and the replacement of older workers with younger, cheaper and bettertrained ones. This set of changes also effected the routes of entry of young people into the labour market. Empirical analyses show (Wolbers, 2008) that the employment opportunities of more recent cohorts of young adults entering the labour market and their chances of stabilizing their employment situation improved significantly since the late 1980s. This is due to good overall economic conditions and strong Dutch economic growth up until the arrival of the economic crisis at the end of the first decade of the new millennium. The improved employment opportunities for young people are, 
however, accompanied by an increased risk for young adult women of getting a fixedterm or part-time contract with their first job, especially the less educated in the service sector. The empirical evidence also shows that, with reference to the first stage of the work career, entry into work under a temporary contract in comparison to a permanent contract increases the risk of subsequent unemployment.

Social protection includes traits of both liberal and universalistic regimes: the latter represented by citizenship-based social assistance and the former by the adoption of workfare policies that condition social security to availability for work. The result is a hybrid transition system: employment-centered (Walther, 2006) with traits of universalism and liberalism (Arts and Gelissen, 2010).

The education system exhibits similar traits and is organized such as to selectively allocate the younger generation to occupational careers in different segments. Vocational training plays a central role, being both school-based (as in France) and company based (like the dual apprenticeship in Germany). Level of education protects against downward mobility: university graduates are forced to deal with episodes of downward mobility in the professional ladder less frequently than secondary education graduates with diplomas.

Norway is usually considered as being a typical model of the Scandinavian area, characterized by a universalistic youth transition regime. The labour market is regulated, income support policies are generous (even for young people without work 
experience), and these are accompanied by significant expenditure in employment services, in incentives to new business activities, and in the direct creation of jobs in the public sector, which provides broad access options, especially for women. High rates of female employment are facilitated by well-developed public childcare services and child benefits aimed at reconciling work and family life. However, there is a strong occupational segregation of women, who tend to work part-time in the field of public welfare with little chances of work career.

Macroeconomic policies are quite intense and are designed to increase business productivity and consequently wages, which support domestic demand. These macroeconomic policies are also supported by active labour market policies aimed at encouraging entry into the labour market.

Employment support combined with a thriving economic situation also favor the school to work transition. Post-compulsory level general and vocational education courses provide a large percentage of school leavers' access to higher education. Young people with a high level of education remain unemployed for a short period, despite the generous support offered by the Norwegian universalistic welfare regime. The duration of the first job is from average to high, especially for those who make their entry into the labour market as an apprentice (Nilsen, 2005). In comparison to men, for young women the search for work is generally shorter and the duration of the first job is longer, even if wages are on average lower. High levels of education favor permanence 
in the labour market after the first entry and protect against the risks of unemployment. Those in education and training exhibit a high propensity to alternately accumulate work experience, a phenomenon that favors the acquisition of practical skills and provides for a smoother transition from school into work (Nilsen, 2005).

The United Kingdom has a typical liberal youth transition regime. The employment system has a low index of employment protection legislation (EPL) and a limited proportion of temporary workers. The British pro-market orientation, in fact, does not provide forms of labour relations regulation that limit workforce reduction. For the same reasons, welfare measures aimed at providing income support for the unemployed are poorly developed, especially as the UK promotes so-called workfare policies. The support offered is consequently ungenerous, of short duration, and is conditional on an active commitment on the part of the unemployed to find a job according to the work first principle.

Even for the most recent cohorts entering the labour market (especially from the 1990s on) the chances of employment were significantly increased, although if in parallel the likelihood of entry with permanent full-time contracts decreased. For the younger cohorts entering work, the chances of experiencing upward mobility, as well as of suffering downward falls, also increased; a phenomenon typical of open employment systems with flexible relations and a hire \& fire model (Gallie, 2007). Many commentators describe the stepwise nature of the early labour market careers of young 
adults in Britain and the strong presence of "informal" channels that enhance mobility in the search for an appropriate and lasting job (Heath and Cheung, 1998; Scherer, 2001, 2005). These characteristics are likely to amplify the problems faced by young people while entering the labour market, because they have to rely on less well-defined (probably more uncertain) procedures to start their careers in the primary labour market. Compared to men, the transition rate into a permanent job for young women is higher. Despite the relative ease of the integration of women into the labour market, there is evidence that low-level entry jobs are more likely to entrap women in the lower segments of the occupational hierarchy, while for men such entry-level jobs more often function as stepping-stones to higher occupational positions (Golsch, 2011).

The education system is largely comprehensive until the age of 16 . The postcompulsory stage is developed and diversified and provides flexibility for vocational and academic options to be created. The level of education plays an important role with respect to inequality. A higher education not only provides quicker entry into the labour market but also provides access to a higher occupational class, which increases the chances of obtaining a permanent contract (Schmelzer, 2008). In addition, a high level of education cushions increased instability in the early careers of young people, because it provides better protection against the risk of unemployment. In this respect, it is mainly low qualified young British who are forced to transit between irregular jobs, low paid jobs, and periods of unemployment (Golsch, 2011). 


\section{Research Hypotheses}

The above are, in brief, the essential dimensions of the institutional context and the main characteristics of the different young adult occupational transition regimes in each of the four countries under observation. The results of the analysis will tell us how the different systems of employment, welfare and education/training that characterize the four countries "filter" the transitions of young adults and design their various career opportunities, focusing on gender differences.

In particular, we will examine in detail four types of transitions:

1) from work into unemployment;

2) from work into inactivity;

3) from inactivity into work;

4) from inactivity to unemployment.

Based on the EU-SILC longitudinal data from 2006-09 to 2009-12, the objective is to first investigate how the risk of experiencing transitions out of and into the labour market varies across the four countries, and whether the deterioration of global economic conditions after 2008 also affected the path of transitions of young adults and how this differs across countries. The second objective is to identify whether women, particular if married or cohabiting, experience different labour market paths compared to their male peers. 
We would have liked to include two other transitions - from unemployment to employment and from unemployment to inactivity - the former as an indicator of positive reintegration in the labour market, the latter on the contrary, suggesting a state of discouragement for young adults who stop looking for a job. However, the small sample size of population unemployed, the skewed distribution and the very limited number of transitions into inactivity prevented a reliable analysis of this phenomenon (see table A.4 in the appendix).

The following hypotheses underpin the analysis (tab. A.1 in the appendix provides a summary of hypotheses):

Hypothesis 1 - Country Effect and Period Effect. Given the different features of youth transition regimes in the four countries, and the deterioration in the global economy following the financial and economic crisis that erupted in 2008 , we wonder whether different levels of risk are observable among the countries studied. More specifically:

1.a we expect to observe a disadvantage for young adults living in less protective youth transition regimes (e.g. Italy and United Kingdom) in terms of increased risk of transition into unemployment and inactivity in comparison with their counterparts living in countries characterized by more protective youth regimes, such as the Netherlands and Norway. However, between these two countries (Italy and UK) we expect higher risks for young Italians compared to young British due to the higher efficacy of the active labour market policies adopted in the UK; 
1.b we expect to observe that this disadvantage is made worse by a deterioration in the possibility of remaining in employment for those respondents who entered the survey in the 2009-10 period (in comparison to those who were interviewed in the period 2006-08). We expect in particular for Italy, which has been harder hit than the other countries studied by the economic crisis, and because the Italian labour market is particularly disadvantageous for young people, including young adults.

With respect to the other transitions considered:

1.c we expect to observe a disadvantage for inactive Italian young adults in repositioning themselves in the labour market. We expect to observe this for Italy in particularly since it has a low protective regime that lacks effective active labour market policies and is characterized by a less dynamic labour market in comparison to the other three countries;

1.d we expect to observe a deterioration in the possibility of exit from being inactive for those who entered in the last observation period (2009-10) compared to those who entered during the period prior to the economic crisis (2006-08). Finally, we expect this disadvantage to be particularly relevant for young adults in Italy compared to those in the other three countries.

Hypothesis 2 -Female disadvantage. Having investigated whether young adults in the four countries experience different levels of risk with respect to transitions into and out 
of the labour market, we investigate whether gender and family-related proxies (being a woman in a partnership for example) are associated with a disadvantage in terms of risk of exiting or re-entering the labour market:

2.a women, in particular if married or cohabiting, experience a higher risk of transitions into inactivity due to the unequal distribution of care activities in families. Further, given the structure of the welfare systems in the countries selected, we expect to find that this disadvantage is observable in Italy, where the welfare state greatly relies on women and family resources for the care and protection of weaker members, and not in the other countries considered;

2.b women, in particular if married or cohabiting, experience lower chances of reentering the labour market after a period of inactivity. Again, given the structure of the welfare state in the countries considered, we expect to find that Italian women, have lower chances compared to their counterpart in the other countries considered.

\section{Data and method}

Using EU-SILC longitudinal data, a working sample was constructed comprising young adults (25-34 years old) resident in the four countries (IT, NL, NO, UK), who were employed $(\mathrm{N}=3,392)$ or inactive $(\mathrm{N}=406)$ at the beginning of the year preceding the interview $^{2}$ and who are followed for 48 months. In order to observe the variability of 
transitions across the years (as a proxy for the deterioration of economic conditions), we pooled together four waves, from EU-SILC 2009 (include years 2006-09) to EU-SILC 2012. The age range considered in our sample allows us to capture the crucial steps of marriage and first childbirth. Indeed, the average age at first marriage for females in 2013 was 30.1 years old in Italy, 30.3 in the Netherlands, 31.5 in UK and Norway (Eurostat, 2017b). Similarly, the mean age of women at birth of first child in 2013 (first year available for Italy) was 30.6 in Italy, 29.4 in the Netherlands, 28.6 in Norway and 28.3 in UK (Eurostat, 2017a)).

The data was analyzed using event history analysis techniques (Allison, 1982; BoxSteffensmeier and Bradford, 2004; Bernardi 2006; Blossfeld, Golsch, and Rohwer, 2006; Mills, 2011), which reconstruct the continuity and change across the life course through longitudinal data and provide for large-scale comparisons between the different cohorts. Event history analysis provides information on time of survival in a status until the occurrence of an event and how much time elapses before an event happens given certain covariates (Mills, 2011). In the case of the EU-SILC longitudinal data, labour market status of each individual is recorded on a monthly basis, which allows the use of continuous time models. Since the assumption of proportionality of hazard, which is required for parametric and semi-parametric models (such as the Cox model) is not verified for our data, a piecewise constant exponential model was used in order to take into account the heterogeneity of risk over time. The piecewise constant exponential 
model is widely used in Event History Analysis as a convenient model that combines the flexibility of not requiring any prior assumption on the shape of the hazard function with the advantage of providing a direct estimation of that hazard function (Kurz et al. 2006; Bernardi 2006; Blossfeld et al. 2007; Mills 2011). Moreover, the piecewise constant exponential model permits the inclusion in the analysis of time-varying variables which are recorded on an annual basis in the survey. Thus, the analysis was carried out using monthly data, but the observation window was divided into a determined number of sub-periods, within which it is assumed that the hazard is constant (as in the exponential model) but which can vary from one interval to another (hence piecewise). In our case, both the theory and the available data prompted the decision to divide the general observation window (consisting of a maximum of 48 months) into 4 intervals, each corresponding to 12 months of observations. The shape of the hazard function for each time period is estimated through time dummy variables included in the model.

The individual transitions were studied separately, following the latent or cause-specific approach (Mills, 2011; page 192) for which the survival analyses are performed separately for each type of event, whilst the other competing event types are treated as right-censored ${ }^{3}$.

For each of the transitions, the dependent variable is the change in status with respect to the initial condition. As an example, in the transition from employed to unemployed the 
dichotomous dependent variable is defined as equal to 1 when an individual becomes unemployed or equal to 0 when an individual retains his/her original condition of employment (or when it is right-censored).

The variables used in the different models are:

- survey cohort - a categorical variable corresponding to the year in which the individual is interviewed and thus enters the sample;

- gender - a dummy variable equal to 1 for women and 0 for men;

- partner - a dummy variable equal to 1 if the individual is married or in a consensual union; equal to 0 otherwise;

- gender and partnership: a categorical variable combining the two characteristics of greater interest for our analysis, gender and partnership. The four-mode variable has single men as reference categories, the other modes are: male with partnership, single female and female with partnership.

- dependent child - a dummy variable equal to 1 if the individual has at least one child younger than 18 years old.

Control variables are:

- type of contract - a categorical variable equal to 1 when the contract is permanent (the reference category), equal to 2 if the contract is temporary, and an extra 
category 3 for controlling for missing responses (for which estimates are not shown);

- level of education - a categorical variable with 3 categories defined according to the ISCED1997 distribution (low = ISCED 0-2; middle = ISCED 3-4; high = ISCED 56). The variable available in EU-SILC for the period considered does not permit to differentiate between general and vocational education, nor apprenticeship (available since 2014 on);

- total unemployment rate - a numerical variable indicating the UE rate at country level for people aged 15-74 years;

- years of job experience - a numerical variable controlling for the left-censoring of past experience in the labour market, expressed in years of job experience;

- time intervals - a categorical variable identifying the four intervals (12 months each) of the piecewise constant exponential model (estimates are not shown).

A summary of the characteristics of the sample of employed and inactive individuals is available in tables A.2 and A.3 in the Appendix.

\section{Results of the research}

From employment into unemployment

Table 1 shows how the relative positions of the four countries considered vary with 
respect to the transition to unemployment. The pooled regression shows an initial disadvantage for young Italians compared to their peers in the Netherlands and Norway, who have lower chances of falling into unemployment. However, when including the control for the structural labour market conditions (proxied by the total unemployment rate) the relative disadvantage loses both statistical and substantial significance (model 1), it even turns into a (non statistically significant) disadvantage for the other three countries when adding all the controls for labour market and family situation (models 3 and 4).

The period effect hypothesized is only partially supported as the negative trend associated to deteriorating conditions after the economic crisis is slightly significant and positive only for the year 2007. Single-country regressions enable the observation of which variables are more associated to the risk of falling into unemployment in each country; in particular, whether a disadvantage associated to gender is observable in some (or all) countries (Table 2). As hypothesized, Italy is the only country showing a slightly significant higher risk of unemployment for those who entered the survey in 2008 compared to those observed since 2006 . On the contrary, a gender disadvantage is not observable for females (not significant and not substantial (Bernardi et al., 2016)). As far as the gender dimension is considered, in the Netherlands and UK having a partner seems to play a protective/activating role, given that the risk of falling into unemployment decreases significantly for men but also, to a lesser extent, to women in 
a partnership (compared to single men). Finally, time dummies suggest a decreasing risk of unemployment through time, which however is only partly significant in Norway and UK.

In conclusion, a slight disadvantage due to changing economic conditions is seen for young Italians in comparison with the other countries (confirming hypothesis 1.b) although significant only for the cohort joining the survey in 2008. On the other side, once controlled for structural labour market condition, the empirical analysis does not support hypothesis 1.a of a greater risk of falling into unemployment for youth living in less protective regimes. Further, gender is not associated with a higher risk of unemployment (as hypothesized in 2.a), whilst results for the Netherlands and UK suggest an activating effect for both men and women in partnership.

Table 1 about here 
For the second type of transition - the exit from the labour market due to inactivity (a "pure inactivity" excluding those who move back to education) - estimates for the pooled sample show an initial higher risk for young adults in the Netherlands. However, when taking into control structural labour market conditions (model 2) and then individual level characteristics (models 3 and 4) the relative risk increases in power and gains statistical significance for both the Netherlands and Norway (model 2), compared to Italy, while UK coefficient remains small in size and not significant.

The year dummies associated with the different periods of entry into the survey indicate a decreasing trend in the risk of inactivity, starting from 2008 on. Estimates for singlecountry regressions (Table 4) show that the transition toward inactivity is not associated with economic conditions, or at least not as hypothesized: first, the trend of decreasing risk of inactivity through time mainly involves the Netherlands and Norway. With respect to family-related characteristics, the disadvantage of women is different among the countries considered. Whilst both single and married/cohabiting women in Italy experience a higher risk of inactivity (compared to single men), in the Netherlands and Norway only married/cohabiting women experience a higher risk of inactivity (compared to single men). In the Netherlands, also married or cohabitating men (compared to single man) have a slightly significant higher risk of transit to inactivity. In contrast, no statistically significant effect in the three countries for single females. 
Finally, the decreasing shape of the hazard function is confirmed for the Netherlands and partly in UK, by which the risk of falling into inactivity decreases through time. However, controls for the interaction between the independent variable for gender and partnership and time dummies do not show a changing pattern of risk (for male and female with or without a partner) across the observation window.

To summarize, the empirical analysis does not seem to support hypothesis 1 .a by which young adults living in Italy and UK (less protective regimes) have a higher risk of transition into inactivity. On the contrary, results seem to suggest that inactivity may be a privileged condition (at least compared to unemployment) which transition - not by chance - is most common in countries with protective youth regimes. In order to investigate further this apparently contradictory result we analyzed the transition adding two new variables related to family characteristics: the equivalized household size and the equivalized household income quintiles (respectively HX050 and HX100 in EUSILC). Due to limited sample size in three out of the four countries, we run this additional control on the pooled sample (single country regressions available upon request). Table A.5 in the appendix shows the estimates of the regression. Models 1 and 2 show that, net of household size, the association between inactivity and women with a partner remains robust and significant, as well as the decreasing trend associated to the period of observation. Including the third interaction term (model 2) estimates show that, among individuals in a partnership, being in a large family reduces the risk of 
inactivity for men while increases the risk for both women in a partnership with a large family and single women in medium and large families (though the estimates are not statistically significant). This seems to suggest that inactivity may still be associated with a traditional view of gender roles, at least in large families, by which the man is the breadwinner and the woman may be more likely to fall into inactivity for care responsibilities. On the other side, the interaction with the level of income of the household (models 3-4) does not provide a clear direction. Indeed, almost all categories (single and in partnership) tend to have lower risk of inactivity at increasing levels of income (though the relationship is not statistically significant). This further analysis, despite of its limitations due to small sample size, seems to confirm the hypothesis of persisting traditional attitudes toward gender roles, which make some home-centered women more prone to opt for inactivity (see Hakim and Dieckhoff et al., 2016)).

Table 3 about here

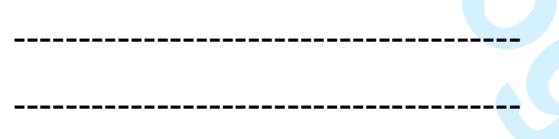

Table 4 about here

From inactivity into employment

The fourth transition, from inactivity to employment, is particularly relevant in terms of gender differences because inactivity mainly involves women (see table A.3). Due to 
the limited sample size of inactive individuals, the empirical analysis is restricted to the pooled sample. Table 5 shows that when all controls are added, there are no statistically significant differences in the risk of exiting inactivity across the country considered, although estimates show that young adults in Norway, the Netherlands and UK (compared to their counterparts in Italy) have a lower risk of re-integration into the labour market after inactivity. The period effect cannot be observed, as estimates are not substantive nor statistically significant. The (positive) risk of exiting inactivity seems to be significantly associated with family related characteristics, with married/cohabiting status having a strikingly different impact on the genders. Indeed, married/cohabiting status plays an activating role for men as well as single young women, who have a higher chance of exiting inactivity toward employment compared to single men.

In conclusion, the empirical analysis goes in the direction of not supporting hypothesis 1.a, foreseeing a particular disadvantage for Italian young adults in repositioning themselves in the labour market. However, the hypothesis linked to a female disadvantage in exiting inactivity (hp 2.b) looks confirmed by the empirical analysis, which shows a significant activating effect of partnership for males and a higher chance of exiting inactivity for single women.

Table 5 about here 


\section{From inactivity into unemployment}

We had wanted to investigate whether a further transition could be observed, i.e. an activation process by which inactive individuals return to job seeking and define themselves as unemployed. Unfortunately, in addition to constrain due to small sample size, the data contains very few cases of this transition, thus influencing the reliability of estimates. Table 6 shows that the activating transition from inactivity to job seeking and availability for a job seems to vary across the years: although not statistically significant, it suggests an activating effect since 2009 onward. Similarly, the estimates for gender and partnership are not statistically significant but suggest an activating effect for men and single women but a retaining effect for women in a partnership. Estimates for country difference suffer of very low reliability.

This finding seems to reinforce the hypothesis that inactivity may be a 'privileged' condition by which individuals living in a protective system can afford to stay longer in inactivity (indeed show a lower risk of exiting toward both employment and unemployment) as a chosen status. Given the limited quality of data available for this analysis we cannot go further in investigating this point, but it represents an interesting future avenue of research, leaving open the question about what the meaning of the status of inactivity across young adults.

Table 6 about here 


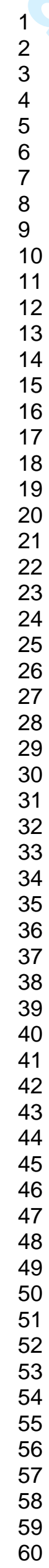




\section{Conclusions}

This article shows how different transition structures foster divergent outcomes (into and out of the labour market) for young adults in general and for women in particular, in the European context. Women are more likely to be affected by temporary work and experience higher risks of unemployment and inactivity. Starting from the assumption that the process of de-standardization of the life course is a trend involving all individuals and encompasses later stages of their working career (not only the entry into the labour market stage), the paper shows that the filtering function played by institutions remains crucial. The filter exercised by the national institutions on the changes taking place for young adults has a selective impact through the shaping of the set of opportunities and constrains faced by individuals, giving rise to what we have defined as young adult occupational transition regimes.

Indeed, the analysis of the set of labour market transitions presented in the paper, although with some limitations due to the small sample size of the particular category under study -young adults- shows that some institutional filters are still effective in sheltering individuals against downward transitions.

As far as downward transitions are concerned, namely exiting the labour market, the analyses have shown that the hypothesized disadvantage of Italian young adults in the risk of falling into unemployment is observed but it is mainly attributable to the structure of the labour market. Indeed, when keeping under control the main labour 
market indicator (total unemployment rate) difference across countries in the risk of exiting the labour market are no longer statistically significant. However, the disadvantage of Italy associated to the worsening of economic conditions after the crisis emerges as hypothesized. Less straightforward is the pattern of transition out of the labour market for inactivity: while we expected to find a pattern similar to unemployment, somehow equating inactivity to 'discouraged unemployment', we found that inactivity is more likely in more protective regimes rather than in Italy and UK. This shows that the risk of exclusion from the labour market due to inactivity follows an own pattern, which mainly involves women with care responsibilities. This preliminary result opens up to further research questions, which we tried to address but, with the data at hand, remain only partially discussed. Further research focused on the drivers of inactivity across European countries can complement this preliminary result, which point to the persistence of a quite traditional division of gender roles in countries with a protective youth transitions system.

Results for upward transition, namely re-integration in the labour market and reactivation after a period of inactivity, do not support the hypothesized disadvantage of young adults living in less protective regimes, in particular for Italian young adults. Results rather stress a substantial role of family-related characteristics and the persistence of traditional division of gender roles, with an activating effect of partnership for men. As for the previous transitions, these results further contribute to 
depict inactivity as a unique labour market status, claiming for greater focus on such a research avenue, both with quantitative and qualitative empirical methods. 


\section{Notes}

${ }^{1}$ The term precariousness refers to the occupational careers of young people, and more precisely to the lack of continuity of employment (job tenure) regardless of the type of contract, the intensity of job turnover, or to the gaps in terms of social protection (Berton et al., 2009; Reyneri 2011; Abbiati 2012; Gualmini and Rizza, 2013)

2 More precisely, individuals were asked their main activity in each month of the year preceding the survey (variables PL210A/PL211A to PL210L/PL211L provide the information from January (A) to December (L) of the year prior to the survey year). In this work individuals are classified as employed (or inactive) if their self-defined status in January (PL210A or PL211 A) was employed (or inactive).

${ }^{3}$ In an early stage of this work the authors considered the feasibility of studying the two transitions using the Cumulative Incidence Curve (CIC) approach. However, we opted to follow the latent approach for two reasons. On the empirical side, some preliminary analysis using the cumulative incidence curve (CIC) compared to the latent approach shows very narrow differences between the estimated hazard provided by the two models. From a theoretical standpoint we followed the recommendation (Pintilie, 2007; StataCorp, 2013) that the choice between a cause-specific (or latent) approach and the cumulative incidence curve approach should depend on the research design. If the main interest lays in estimating the effect of a certain variable on the risk of experiencing the outcome event, then the cause-specific approach, which considers the competing event 
as censored, is a suitable choice. The competing risk approach is more appropriate when the focus is on estimating the incidence of the outcome variable (the probability of the specific event to occur). 


\section{References}

Abbiati G (2012) Instabilità precarietà, insicurezza. Cosa si intende quando si parla di insicurezza del lavoro. Stato e mercato 2: 323-356.

Allison PD (1982) Discrete-Time Methods for the Analysis of Event Histories. Sociological Methodology 13 (January): 61-98.

Arts W and Gelissen J (2010) Models of the Welfare State. In: Castles F et al. (eds.) The Oxford Handbook of the Welfare State. Oxford: Oxford University Press, pp.569 83.

Barbieri, P., and Scherer, S. (2005) Le conseguenze sociali della flessibilizzazione del lavoro in Italia. Stato e mercato 2: 291-322.

Bernardi F (2006) Análisis de la historia de acontecimientos. Madrid: Centro de Investigaciones Sociológicas.

Bernardi F, Chakhaia L and Leopold L (2016) 'Sing Me a Song with Social Significance': The (Mis)Use of Statistical Significance Testing in European Sociological Research. European Sociological Review: jcw047.

Berton F, Richiardi M, Sacchi S (2009) Flex-insecurity: perché in Italia la flessibilità diventa precarietà. Bologna: Il Mulino.

Blossfeld HP, Klijzing E, Mills M and Kurz K (eds.) (2005) Globalization, uncertainty and youth in society, London: Routledge.

Blossfeld HP, Buchholz S, Bukodi E, Kurz K (eds.) (2008) Young Workers, Globalization and the labor Market. Comparing Early Working Life in Eleven Countries. Cheltenham: Edward Elgar.

Blossfeld HP, Golsch K, Rohwer G (2006) Event History Analysis with Stata. Mahwah, NJ: Lawrence Erlbaum Associates.

Blossfeld, HP, and Hofmeister HA, (eds) (2008) Globalization, Uncertainty and Women's Careers: An International Comparison. Cheltenham, UK; Northhampton, MA: Edward Elgar; 
Blossfeld, H.P., and Drobnič S., (eds) (2001) Careers of Couples in Contemporary Societies. Oxford [UK]; New York: Oxford University Press.

Blossfeld, H.P., Buchholz, S., Hofäcker, D., Kolb, K. 2011. Globalized Labor Markets and Social Inequality in Europe. New York: Palgrave Macmillan.

Box-Steffensmeier J and Bradford SJ (2004) Event History Modeling: A Guide for Social Scientists. Cambridge; NY: Cambridge University Press.

Breen R (2005) Explaining Cross-national Variation in Youth Unemployment. Markets and Institutional Factors. European Sociological Review 21(2): 125-34.

Brzinsky-Fay C (2007) Lost in Transition? Labour Market Entry Sequences of School Leavers in Europe. European Sociological Review 23(4): 409-422.

Clasen, J and Clegg D (eds.) (2011) Regulating the risk of unemployment: National adaptations to post-industrial labour markets in Europe. Oxford: Oxford University Press.

De Luigi N and Rizza R (2011) La vulnerabilità dei giovani nel mercato del lavoro italiano: dinamiche e persistenze Sociologia del lavoro 124: 117-147.

Dieckhoff M, Gash V, Mertens A, et al. (2016) A stalled revolution? What can we learn from women's drop-out to part-time jobs: A comparative analysis of Germany and the UK. Research in Social Stratification and Mobility 46: 129-140.

Elder GH Jr. (1985). Perspectives on the life course. Ithaca New York: Cornell University Press.

Elder GH., Kirkpatrick JM, Crosnoe R (2003) The Emergence and Development of Life Course Theory. In: Jeylan TM and Shanahan MJ (eds.). Handbook of the Life Course. Springer, pp. 3-19.

Esping-Andersen G (1990) The Three Worlds of Welfare Capitalism. Cambridge: Polity Press.

Esping-Andersen G (1999), Social Foundations of Postindustrial Economies. Oxford: Oxford University Press. 
Esping-Andersen G and Regini M. (2000) Why deregulate labour markets? Oxford: Oxford University Press.

Eurostat (2016) 'Europe in figures' Available at: http://ec.europa.eu/eurostat/statisticsexplained/index.php/Europe_in_figures_-_Eurostat_yearbook

Eurostat (2017a) Fertility indicators. Available from: http://appsso.eurostat.ec.europa.eu/nui/show.do?dataset=demo_find\&lang=en (accessed 1 August 2017).

Eurostat (2017b) Marriage indicators. Available from: http://appsso.eurostat.ec.europa.eu/nui/show.do?dataset=demo_nind\&lang=en (accessed 1 August 2017).

Furlong A (ed.) (2009) Handbook of Youth and Young Adulthood. New Perspectives and Agendas. London; New York: Routledge.

Gallie D (Eds) (2007) Employment Regimes and the Quality of Work. Oxford: Oxford University Press.

Gallie, D and Paugam, S (eds) (2000) Welfare regimes and the experience of unemployment in Europe. Oxford: Oxford University Press.

Gangl M (2003) The only way is up? Employment Protection and Job Mobility among recent entrants to European labour markets. European Sociological Review 19 (5): 42949.

Golsch K (2011) La flessibilità come principio guida: conseguenze dell'inserimento lavorativo, i piani di vita individuali e le decisioni legate alla formazione di una famiglia da parte dei giovani in Gran Bretagna. Sociologia del lavoro, 124: 58-74.

Gualmini, E and Rizza R (2013) Le politiche del lavoro. Bologna: Il Mulino.

Hall P and Soskice D (2001) Varieties of capitalism: the institutional foundations of comparative advantage. Oxford: Oxford University Press.

Heath A and Cheung SY (1998) Education and occupation in Britain. New York, NY: Clarendon Press. 
Heinz WR (2009) Youth Transitions in an Age of Uncertainty. In: Furlong A (ed.) Handbook of Youth and Young Adulthood. New Perspectives and Agendas. London; New York: Routledge.

Heinz WR and Marshall VW (eds) (2003) Social Dynamics of the Life Course: Transitions, Institutions, and Interrelations. New York: Aldine de Gruyter.

Kurz K, Hillmert S and Grunow D (2006) Increasing instability in the employment careers of West German men? A comparison of the birth cohorts 1940, 1955 and 1964. In Blossfeld HP, Mills M and Bernardi F (eds) Globalization, Uncertainity and Men's Carrers: An international comparison. Chelthenam, UK: Edward Elgar Press, pp. 75116.

Lewis, J., Campbell, M. e Huerta, C. (2008), Patterns of Paid and Unpaid Work in Western Europe: Gender, Commodification, Preferences and Implications for Policy, in «Journal of European Social Policy», 18, 1, pp. 21-37.

Mayer KU (2009) New Directions in Life Course Research. Annual Review of Sociology 35: 413-433

Mills M (2011) Introducing Survival and Event History Analysis. Los Angeles, CA; London: SAGE.

Mortimer JT, Oesterle S and Krüger H (2005) Age Norms, Institutional Structures, And The Timing Of Markers Of Transition To Adulthood. Advances in Life Course Research 9: 175-203.

Mortimer JT, Oesterle S and Krüger H (2005) Age Norms, Institutional Structures, and the Timing of Markers of Transition to Adulthood. Advances in Life Course Research 9: 175-203.

Naldini M. and Saraceno C (2011) Conciliare famiglia e lavoro. Bologna: Il Mulino.

Nilsen OA (2005) Transition to Adulthood in Norway. In: Blossfeld HP, Klijzing E, Mills M, Kurz K (eds) Globalization, Uncertainty and Youth in Society. London/New York: Routledge.

Pintilie M (2007) Analysing and interpreting competing risk data. Statistics in Medicine 26(6): 1360-1367. 
Piore MJ and Sabel CF (1987) Le due vie dello sviluppo industriale. Produzione di massa e produzione flessibile. Torino: Isedi.

Piotrowski M, Kalleberg A, Rindfuss R, (2015), Contingent Work Rising: Implications for the Timing of Marriage in Japan. Journal of Marriage and Family 77: 1039-1056

Ranci C (ed.) (2010). Social vulnerability in Europe: the new configuration of social risks. New York: Palgrave Macmillan.

Reyneri E (2011) Sociologia del mercato del lavoro. Bologna: Il Mulino.

Reyneri E and Pintalti F (2013) Dieci domande su un mercato del lavoro in crisi. Bologna: Il Mulino.

Sackmann R and Wingens M (2003) From Transitions to Trajectories. Sequence Types. In: Heinz WR (ed.) Social Dynamics of the Life Course. Transitions, Institutions, and Interrelations. New York: Aldine de Gruyter, pp. 93-115.

Saraceno C and Keck W (2010) Can we Identify Intergenerational Policy Regimes in Europe?, in «European Societies», 5, pp. 675-696.

Scherer S (2001) Early Career Patterns: A Comparison of Great Britain and West Germany. European Sociological Review, 17 (2): 119-144.

Scherer S (2005) Patterns of Labour Market Entry - Long Wait or Career Instability? An Empirical Comparison of Italy, Great Britain and West Germany. European Sociological Review, 21 (5): 427-440.

Schmelzer P (2008) Increasing Employment Instability among Young People? Labour Market Entries and Early Career in Great Britain since the 1980s. In: Blossfeld HP, Buchholz S, Bukodi E, Kurz K (eds) Young Workers, Globalization and the labour Market. Comparing Early Working Life in Eleven Countries. Cheltenham: Edward Elgar

Schmid G (2002) Wege in eine neue Vollbeschäftigung. Frankfurt/New York: Campus.

Schofer E and Meyer JW (2005) The Worldwide Expansion of Higher Education in the Twentieth Century. American Sociological Review 70(6): 898-920. 
Standing G (2011) The Precariat: The New Dangerous Class. London and New York, Bloomsbury Academic

StataCorp (2013) stcrreg - Competing-risks regression, in: Stata Survival Analysis And Epidemiological Tables Reference Manual. Release 13. Stata Press, College Station, TX, pp. 200-225.

Taylor-Gooby P (ed.) (2004) New Risks, New Welfare: The Transformation of the European Welfare State. Oxford: Oxford University Press.

Trigilia C (2009) Sociologia economica. Bologna: Il Mulino.

Visser J and Hemerijck A (1997) A Dutch Miracle: Job Growth, Welfare Reform and Corporatism in the Netherlands. Amsterdam: Amsterdam University Press.

Vosko L (2000) Temporary Work: The Gendered Rise of Precarious Employment Relationship. Toronto: University of Toronto Press

Walther A (2006) Regimes of youth transitions. Choice, flexibility and security in young people's experiences across different European contexts. Young, 14 (2): 119139.

Wolbers M (2008) Increasing Labour Market Instability among Young People? Labour Market Entry and Early Career Development among School-Leavers in the Netherlands since the Mid-1980s. In: Blossfeld HP, Buchholz S, Bukodi E, Kurz K (eds) Young Workers, Globalization and the labour Market. Comparing Early Working Life in Eleven Countries. Cheltenham: Edward Elgar. 


\section{Appendix}

Table A.1 about here

Table A. 2 about here

Table A.3 about here

Table A.4 about here

Table A.5 about here 
Page 41 of 52

International Journal of Sociology and Social Policy

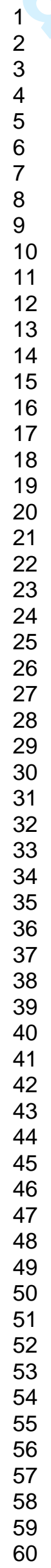


Table 1 Transition from employment to unemployment. Regression coefficients from pooled sample

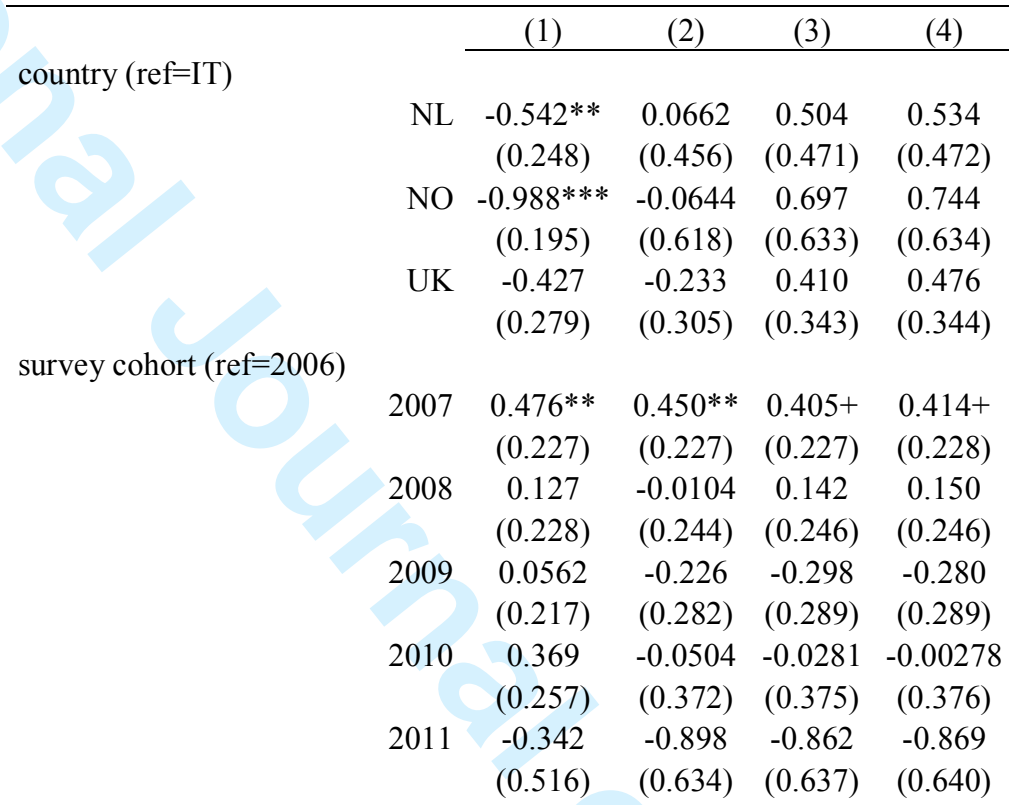

Controls

unemployment rate (15-74 years)

temporary contract

level of education

gender and partnership dependant child(children) years spent in paid work time dummies

$\begin{array}{lll}Y & Y & Y \\ & Y & Y\end{array}$

Observations

$\begin{array}{llll}10,035 & 10,035 & 9,936 & 9,936\end{array}$

Notes: Standard errors in parentheses; $* * * \mathrm{p}<0.01, * * \mathrm{p}<0.05,+\mathrm{p}<0.1$.

Source: Own calculations based on EU-SILC longitudinal database (UDB 2009-2012) 
Table 2 Transition from employment to unemployment -single country regressions

\begin{tabular}{|c|c|c|c|c|c|c|c|c|}
\hline \multirow{2}{*}{ survey cohort (ref=2006) } & \multicolumn{2}{|c|}{ (IT) } & \multicolumn{2}{|c|}{$(\mathrm{NL})$} & \multicolumn{2}{|c|}{$(\mathrm{NO})$} & \multicolumn{2}{|c|}{ (UK) } \\
\hline & & & & & & & & \\
\hline 2007 & 0.496 & $(0.323)$ & 1.001 & $(0.727)$ & 0.0830 & $(0.386)$ & -15.31 & $(3,786)$ \\
\hline 2008 & $0.580+$ & $(0.338)$ & -0.596 & (1.088) & -0.339 & $(0.466)$ & 1.095 & $(8.060)$ \\
\hline 2009 & 0.178 & $(0.453)$ & 0.234 & $(0.676)$ & -0.998 & $(0.670)$ & 0.483 & $(8.625)$ \\
\hline 2010 & 0.659 & $(0.570)$ & 0.0268 & $(0.917)$ & -15.16 & $(2,107)$ & 0.0330 & (9.128) \\
\hline 2011 & -0.251 & $(0.967)$ & 0.331 & $(1.036)$ & -15.79 & $(4,393)$ & -16.54 & $(3,314)$ \\
\hline \multicolumn{9}{|c|}{ gender and partnership (ref $=$ male, single } \\
\hline male with partner & -0.0469 & $(0.251)$ & $-2.635 * *$ & $(1.094)$ & -0.390 & $(0.419)$ & $-1.735 * *$ & $(0.819)$ \\
\hline female, single & 0.330 & $(0.261)$ & 0.298 & $(0.561)$ & -0.0821 & $(0.515)$ & -1.570 & $(1.160)$ \\
\hline female with partner & 0.0268 & $(0.277)$ & $-1.220+$ & $(0.681)$ & -0.709 & $(0.470)$ & $-1.436+$ & $(0.750)$ \\
\hline \multicolumn{9}{|l|}{ time dummies (ref $=0-12$ months) } \\
\hline 13-24 months & -0.204 & $(0.225)$ & 0.128 & $(0.537)$ & -0.0145 & $(0.375)$ & $-1.509+$ & $(0.892)$ \\
\hline 25-36 months & -0.334 & $(0.317)$ & -0.694 & $(0.817)$ & -0.500 & $(0.444)$ & -1.546 & (1.605) \\
\hline $37-48$ months & -0.546 & $(0.481)$ & -0.508 & $(0.855)$ & $-2.632 * *$ & (1.054) & -17.56 & $(2,598)$ \\
\hline Observations & 4,227 & & 1,168 & & 3,716 & & 825 & \\
\hline
\end{tabular}

Notes: Standard errors in parentheses; $* * * \mathrm{p}<0.01, * * \mathrm{p}<0.05,+\mathrm{p}<0.1$.

Controls included: temporary contract, educational level, years of job experience, total unemployment rate, dependent child(ren).

Source: Own calculations based on EU-SILC longitudinal database (UDB 2009-2012) 
Table 3 Transition from employment to inactivity. Regression estimates from pooled sample

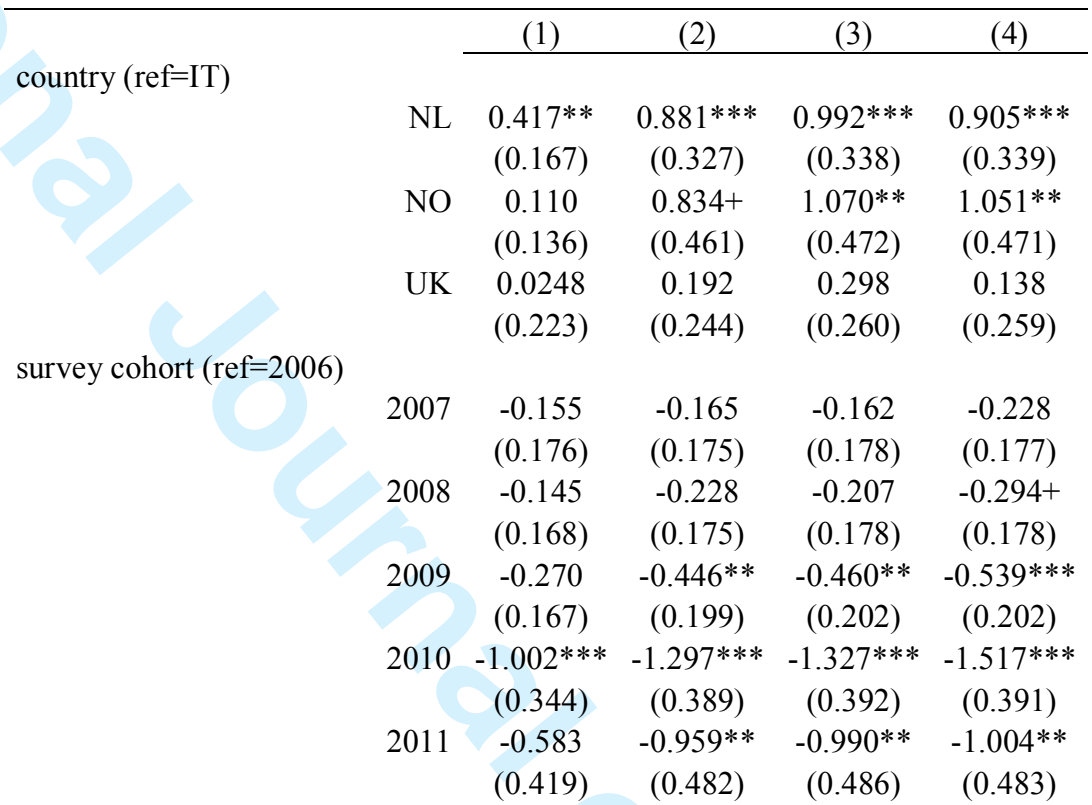

\section{Controls}

unemployment rate (15-74 years)

temporary contract

educational level attained

gender and partnership dependant child(children) years spent in paid work time dummies

$\begin{array}{cccc} & & & \\ & & Y & Y \\ & & Y & Y \\ & & Y & Y \\ & & & Y \\ Y & Y & Y & Y \\ Y & Y & Y & Y \\ 10,035 & 10,035 & 9,936 & 9,936 \\ \end{array}$

Observations

Notes: Standard errors in parentheses; $* * * \mathrm{p}<0.01, * * \mathrm{p}<0.05,+\mathrm{p}<0.1$.

Source: Own calculations based on EU-SILC longitudinal database (UDB 2009-2012) 
Table 4 Transition from employment to inactivity. Single country regressions

\begin{tabular}{|c|c|c|c|c|c|c|c|c|}
\hline & \multicolumn{2}{|c|}{ (IT) } & \multicolumn{2}{|c|}{$(\mathrm{NL})$} & \multicolumn{2}{|c|}{$(\mathrm{NO})$} & \multicolumn{2}{|c|}{ (UK) } \\
\hline \multicolumn{9}{|l|}{ survey cohort $(\mathrm{ref}=2006)$} \\
\hline 2007 & 0.0882 & $(0.343)$ & -0.0674 & $(0.484)$ & -0.210 & $(0.248)$ & -16.62 & $(3,525)$ \\
\hline 2008 & 0.0257 & $(0.343)$ & -0.872 & $(0.536)$ & -0.192 & $(0.264)$ & -2.408 & $(9.691)$ \\
\hline 2009 & 0.290 & $(0.414)$ & $-1.264 * *$ & $(0.544)$ & $-0.552+$ & $(0.306)$ & -7.636 & $(10.05)$ \\
\hline 2010 & -0.356 & $(0.613)$ & $-1.903+$ & $(1.045)$ & -13.71 & (521.3) & -8.443 & $(10.93)$ \\
\hline 2011 & 0.580 & $(0.788)$ & -14.76 & $(930.3)$ & 0.566 & $(1.024)$ & -8.681 & $(11.45)$ \\
\hline \multicolumn{9}{|c|}{ gender and partnership (ref=male, single) } \\
\hline male with partner & 0.204 & $(0.342)$ & $1.180+$ & $(0.626)$ & -0.0875 & $(0.426)$ & 15.64 & $(2,559)$ \\
\hline female, single & $0.967 * * *$ & $(0.328)$ & 0.431 & $(0.772)$ & -0.297 & $(0.680)$ & -0.263 & $(3,535)$ \\
\hline female with partner & $1.852 * * *$ & $(0.283)$ & $1.401 * *$ & $(0.631)$ & $1.775 * * *$ & $(0.376)$ & 17.59 & $(2,559)$ \\
\hline \multicolumn{9}{|c|}{ time dummies (ref $=0-12$ months) } \\
\hline 13-24 months & -0.294 & $(0.223)$ & -0.410 & $(0.381)$ & 0.0304 & $(0.239)$ & -0.810 & $(0.583)$ \\
\hline 25-36 months & -0.152 & $(0.274)$ & $-1.298 * *$ & $(0.549)$ & -0.208 & $(0.254)$ & $-5.383 * * *$ & (1.628) \\
\hline $37-48$ months & -0.630 & $(0.463)$ & $-1.366 * *$ & $(0.570)$ & $-1.251 * * *$ & $(0.358)$ & -22.44 & $(2,098)$ \\
\hline Observations & 4,227 & & 1,168 & & 3,716 & & 825 & \\
\hline
\end{tabular}

Notes: Standard errors in parentheses; $* * * p<0.01, * * \mathrm{p}<0.05,+\mathrm{p}<0.1$.

Controls included: temporary contract, educational level, years of job experience, dependent child(ren); total unemployment rate

Source: Own calculations based on EU-SILC longitudinal database (UDB 2009-2012) 
Table 5 Transition from inactivity to employment

\begin{tabular}{lccc}
\hline & & (Model 1) & $(0.874)$ \\
\hline country (ref=IT) & NL & -0.422 & $(1.123)$ \\
& NO & -1.697 & $(0.424)$ \\
& UK & -0.488 & $(0.369)$ \\
survey cohort (ref=2006) & & $(0.378)$ \\
& 2007 & 0.177 & $(0.525)$ \\
& 2008 & 0.0614 & $(0.677)$ \\
& 2009 & 0.0137 & $(1.191)$ \\
gender and partnership (ref=male single) & 2010 & 1.042 & $(0.673)$ \\
male with partner & 2011 & -1.005 & $(0.468)$ \\
female single & & $(0.406)$
\end{tabular}

Observations 584

Notes: Standard errors in parentheses; $* * * \mathrm{p}<0.01,{ }^{* *} \mathrm{p}<0.05,+\mathrm{p}<0.1$.

Controls included: time dummies, educational level, years of job experience, dependent child(ren), total unemployment rate.

Source: Own calculations based on EU-SILC longitudinal database (UDB 2009-2012) 
Table 6 Transition from inactivity to unemployment

\begin{tabular}{lccc}
\hline & & \multicolumn{3}{c}{ (Model 1) } \\
\hline country (ref=IT) & NL & -17.50 & $(7,134)$ \\
& NO & $-3.823^{* *}$ & $(1.947)$ \\
UK & -0.568 & $(1.175)$ \\
survey cohort (ref=2006) & & & \\
& 2007 & 0.424 & $(0.464)$ \\
2008 & -0.569 & $(0.657)$ \\
2009 & 0.600 & $(0.742)$ \\
2010 & 1.099 & $(0.907)$ \\
2011 & 0.479 & $(1.426)$ \\
gender \& partnership (ref=male single) & & \\
male with partner & 0.539 & $(1.141)$ \\
female single & 0.349 & $(0.670)$ \\
female with partner & -0.744 & $(0.514)$
\end{tabular}

Observations

584

Notes: Standard errors in parentheses; $* * * \mathrm{p}<0.01, * * \mathrm{p}<0.05,+\mathrm{p}<0.1$.

Controls included: time dummies, educational level, years of job experience, dependent child(ren), total unemployment rate.

Source: Own calculations based on EU-SILC longitudinal database (UDB 2009-2012) 
Table A.1 Summary of hypotheses

\begin{tabular}{|c|c|c|c|}
\hline & Dependent variable & Independent variable & Expected direction of relation \\
\hline Hypothesis 1 & \multicolumn{3}{|c|}{ Country and Period Effect } \\
\hline H 1.a & $\begin{array}{l}\text { from employment } \rightarrow \\
\text { unemployment or } \\
\text { inactivity }\end{array}$ & $\begin{array}{l}\text { country of residence } \\
\text { (as proxy for transition } \\
\text { regime) }\end{array}$ & $\begin{array}{l}\text { disadvantage of Italians (positive sign }+ \text { ) } \\
\text { compared to NL, NO, UK }\end{array}$ \\
\hline H 1.b & $\begin{array}{l}\text { from employment } \rightarrow \\
\text { unemployment or } \\
\text { inactivity }\end{array}$ & $\begin{array}{l}\text { period of entry into } \\
\text { observation } \\
\text { (as proxy for changing } \\
\text { economic conditions after } \\
\text { the crisis) }\end{array}$ & $\begin{array}{l}\text { disadvantage of individuals observed in } \\
2009-10 \text { (positive sign }+ \text { ) compared to those } \\
\text { in } 2006-08\end{array}$ \\
\hline H 1.c & $\begin{array}{l}\text { from unemployment or } \\
\text { inactivity } \rightarrow \\
\text { employment }\end{array}$ & $\begin{array}{l}\text { country of residence } \\
\text { (as proxy for transition } \\
\text { regime) }\end{array}$ & $\begin{array}{l}\text { disadvantage of Italians (negative sign -) } \\
\text { compared to NL, NO, UK }\end{array}$ \\
\hline H 1.d & $\begin{array}{l}\text { from unemployment or } \\
\text { inactivity } \rightarrow \\
\text { employment }\end{array}$ & $\begin{array}{l}\text { period of entry into } \\
\text { observation } \\
\text { (as proxy for changing } \\
\text { economic conditions after } \\
\text { the crisis) }\end{array}$ & $\begin{array}{l}\text { disadvantage of individuals observed in } \\
2009-10 \text { (negative sign -) compared to those } \\
\text { in 2006-08 }\end{array}$ \\
\hline Hypothesis 2 & \multicolumn{3}{|l|}{ Female disadvantage } \\
\hline \multirow[t]{2}{*}{ H 2.a } & $\begin{array}{l}\text { from employment } \rightarrow \\
\text { inactivity }\end{array}$ & $\begin{array}{l}\text { gender and family } \\
\text { situation }\end{array}$ & $\begin{array}{l}\text { disadvantage (positive sign }+ \text { ) of } \\
\text { married/cohabitating women compared to } \\
\text { single women }\end{array}$ \\
\hline & $\begin{array}{l}\text { from employment } \rightarrow \\
\text { inactivity }\end{array}$ & $\begin{array}{l}\text { gender, family situation } \\
\text { and country }\end{array}$ & $\begin{array}{l}\text { greater disadvantage (positive sign }+ \text { ) of } \\
\text { married/cohabitating women in Italy } \\
\text { compared to peers in NO, NL, UK }\end{array}$ \\
\hline \multirow[t]{2}{*}{ H 2.b } & $\begin{array}{l}\text { from unemployment or } \\
\text { inactivity } \rightarrow \\
\text { employment }\end{array}$ & $\begin{array}{l}\text { gender and family } \\
\text { situation }\end{array}$ & $\begin{array}{l}\text { disadvantage (negative sign -) of } \\
\text { married/cohabitating women compared to } \\
\text { single women }\end{array}$ \\
\hline & $\begin{array}{l}\text { from unemployment or } \\
\text { inactivity } \rightarrow \\
\text { employment }\end{array}$ & $\begin{array}{l}\text { gender, family situation } \\
\text { and country }\end{array}$ & $\begin{array}{l}\text { greater disadvantage (negative sign -) of } \\
\text { married/cohabitating women in Italy } \\
\text { compared to peers in NO, NL, UK }\end{array}$ \\
\hline
\end{tabular}


Table A.2 Descriptive statistics of the sample - employed individuals

\begin{tabular}{|c|c|c|c|c|c|}
\hline 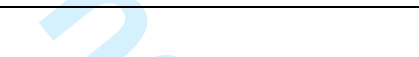 & IT & NL & $\mathrm{NO}$ & UK & Total \\
\hline $\mathrm{N}$ & 1,344 & 409 & 1,189 & 450 & 3,392 \\
\hline N (\%) & 39.6 & 12.1 & 35.1 & 13.3 & 100 \\
\hline female $(\%)$ & 42.7 & 51.6 & 43.2 & 52.9 & 45.3 \\
\hline $\begin{array}{l}\text { married or in a conensual } \\
\text { union }(\%)\end{array}$ & 52.0 & 66.3 & 75.9 & 75.6 & 65.2 \\
\hline \multicolumn{6}{|l|}{ level of education (\%) } \\
\hline low & 27.7 & 10.6 & 8.5 & $(4.0)$ & 15.9 \\
\hline medium & 53.8 & 44.0 & 39.4 & 53.0 & 47.6 \\
\hline high & 18.5 & 45.5 & 52.1 & 42.9 & 36.6 \\
\hline \multicolumn{6}{|l|}{ type of contract (\%) } \\
\hline permanent & 65.6 & 77.8 & 75.0 & 68.7 & 70.8 \\
\hline temporary & 11.8 & 14.2 & 8.8 & (1.3) & 9.7 \\
\hline missing & 22.6 & $(8.1)$ & 16.2 & 30.0 & 19.6 \\
\hline
\end{tabular}

Note: values shown in brackets have small sample size (20-49), following Eurostat Guidelines for Publication Source: EU-SILC longitudinal database (UDB 2009-2012) 
Table A.3 Descriptive statistics of the sample - inactive individuals

\begin{tabular}{|c|c|}
\hline 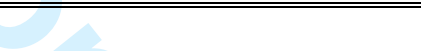 & Pooled sample \\
\hline $\mathrm{N}$ & 406 \\
\hline educational attainment (\%) & \\
\hline low & 41.5 \\
\hline medium & 48.1 \\
\hline high & 10.4 \\
\hline female $(\%)$ & 85.5 \\
\hline married or in a c. union $(\%)$ & 73.9 \\
\hline
\end{tabular}

Source: EU-SILC longitudinal database (UDB 2009-2012) 
Table A.4 Unemployed individuals by country

\begin{tabular}{lcc}
\hline \hline country & Unemployed at $\mathrm{t}_{0}(\mathrm{~N})$ & Percent (\%) \\
\hline $\mathrm{IT}$ & 282 & 78.1 \\
$\mathrm{NL}$ & 10 & 2.3 \\
$\mathrm{NO}$ & 48 & 13.3 \\
$\mathrm{UK}$ & 21 & 5.8 \\
Total & 361 & 100 \\
\hline \hline Source: Own calculations based on EU-SILC longitudinal database (UDB 2009-2012)
\end{tabular}

Source: Own calculations based on EU-SILC longitudinal database (UDB 2009-2012) 
Table A.5 Transition from employment to inactivity with interactions. Pooled sample.

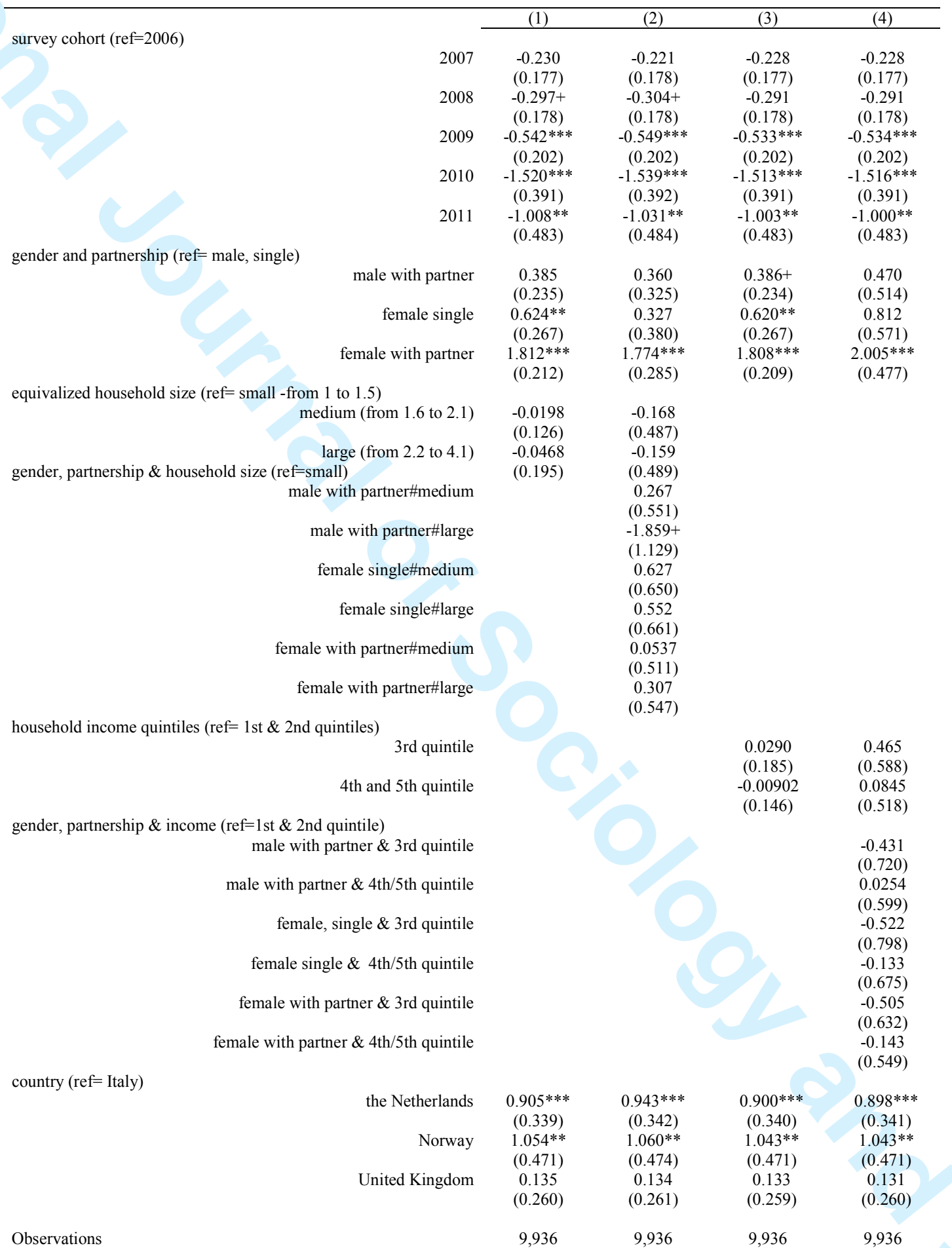

Notes: Standard errors in parentheses; $* * * \mathrm{p}<0.01, * * \mathrm{p}<0.05,+\mathrm{p}<0.1$.

Controls included: temporary contract, educational level, years of job experience, total unemployment rate, dependent child(ren). Source: Own calculations based on EU-SILC longitudinal database (UDB 2009-2012) 